Article

\title{
Hydrodistillation Extraction Kinetics Regression Models for Essential Oil Yield and Composition in Juniperus virginiana, J. excelsa, and J. sabina
}

\author{
Ivanka B. Semerdjieva ${ }^{1}$, Santosh Shiwakoti ${ }^{2}{ }^{\oplus}$, Charles L. Cantrell $^{3}$, \\ Valtcho D. Zheljazkov ${ }^{4, *}$, Tess Astatkie ${ }^{5}$ D , Vicki Schlegel ${ }^{6}$ and Tzenka Radoukova ${ }^{7}$ \\ 1 Department of Botany and Agrometeorology, Agricultural University, Mendeleev 12, 4000 Plovdiv, Bulgaria; \\ v_semerdjieva@abv.bg \\ 2 Department of Crop and Soil Sciences, Washington State University, 225 Johnson Hall, Pullman, WA 99163, \\ USA; Santosh.Shiwakoti@wsu.edu \\ 3 National Center for Natural Products Research, Agricultural Research Service, United States Department of \\ Agriculture, University, University, MS 38677, USA; clcantr1@olemiss.edu \\ 4 Department of Crop and Soil Science, Oregon State University, 3050 SW Campus Way, 109 Crop Science \\ Building, Corvallis, OR 97331, USA \\ 5 Faculty of Agriculture, Dalhousie University, PO Box 550, Truro, NS B2N 5E3, Canada; astatkie@dal.ca \\ 6 Department of Food Science and Technology, University of Nebraska - Lincoln, 327 Food Technology \\ Complex, Lincoln, NE 68583, USA; vschlegel3@unl.edu \\ 7 Department of Botany and Methods of Biology Teaching, Faculty of Biology, University of Plovdiv "Paisii \\ Hilendarski", 24 Tzar Assen, 4000 Plovdiv, Bulgaria; kiprei@abv.bg \\ * Correspondence: valtcho.jeliazkov@oregonstate.edu; Tel: 1-541-737-5877; Fax: 1-541-737-1589
}

Received: 14 February 2019; Accepted: 7 March 2019; Published: 11 March 2019

check for updates

\begin{abstract}
The chemical profile and antioxidant capacity of Juniperus virginiana, J. excelsa, and J. sabina essential oil (EO) fractions as a function of time was the subject of this study. The hypothesis was that, capturing $\mathrm{EO}$ in sequential timeframes during hydrodistillation would generate fractions containing unique compositions and antioxidant capacity. In J. virginiana, the highest limonene (43\%) was found in the 0-5 min oil fraction, with safrole (37\%) being highest in the 10-20 and 20-40 min fractions, and elemol (34\%) being highest in the 160-240 min fraction. In J. excelsa, $\alpha$-pinene (34-36\%) was the highest in the 0-5 min fraction and in the control (non-stop 0-240 min distillation) oil, limonene (39\%) was the highest in the 0-10 min fractions and cedrol (50-53\%) was the highest in the 40-240 min fractions. In J. sabina, sabinene (80\%) was highest in the 0-3 min fraction. The highest antioxidant capacity of $J$. virginiana was demonstrated by the 5-10 min fraction; the one in J. sabina by the 3-10 min fraction; and, the one in J. excelsa, by the control. The kinetics regression models that were developed can predict EO composition of the three juniper species eluted at different timeframes. Various industries could benefit from the results from this study.
\end{abstract}

Keywords: savin; eastern red cedar; greek juniper; monoterpenes; limonene; safrole; elemol; $\alpha$-pinene; cedrol; sabinene

\section{Introduction}

Juniperus is one of the main genera of the Cupressaceae family. Some of the species, such as J. virginiana L. (eastern redcedar, red cedar juniper), is widely distributed indigenous species in the eastern parts of the United States and Canada, while others, such as J. excelsa Bieb (Greek juniper, tree juniper) and J. sabina L. (savin, Cossack juniper), occupy specific and rather limited environments. J. excelsa prefers the Mediterranean climate and it is distributed across the Eastern Mediterranean, 
mainly in Northeastern Greece, Southern Bulgaria, Turkey, Syria, Iran, Lebanon, and the Caucasus Mountains [1]. J. sabina has a very limited, fragmented distribution range in southern and northern Europe, Crimea, Caucasus, Siberia, Kazakhstan, Mongolia, and Asia Minor, which is most probably due to its low reproductive potential.

Juniperus species contain a diverse metabolic profile (coumarins, flavonoids, lignans, sterols, terpenoids, etc.) [2], which is why various extracts of these products are used in several industries. Products of different types of juniper are used in fragrances, cosmetics [3]; in the food and beverage industry [4,5]; have shown promise as ingredients in pharmaceutical products [6-10]; against insects [11,12]; and, as antioxidants [13-15].

Generally, a large variation in the chemical composition of the essential oil (EO) has been found in different juniper species due to: (1) within species and intra-population variability [16]; (2) different gender affiliation, as most junipers are dioecious [17]; (3) ecological characteristics of the habitats [18]; (4) different extraction methods [7,19,20]; (5) plant parts (leaves, galbuli, wood, or any mixes of those) [10,21-23]; (6) time (season) of sampling [18,19,24,25]; and, (7) the type and duration of the distillation $[25,26]$.

Juniperus virginiana has been the subject of phytochemical, biological, and biosystematics investigations in a number of studies [7,16-18,20,27-29]. J. virginiana EO has shown activity against insects and pathogens [30,31]. Ethno-pharmacological studies for J. excelsa have shown that the extracts of the species were used to treat tuberculosis, jaundice, colds, coughs, and bronchitis [32-34]; Djeridane et al. [13] and Emami et al. [14,35] have reported antiviral and antioxidant activities. Thappa et al. [36] reported that J. excelsa had the potential for the commercial production of cedrol, an important aroma compound. Additionally, cedrol is the first identified oviposition attractant for African malaria vectors [37,38]. The work of von Rudloff [39] and Gao et al. [12] reflected research on the phytochemical composition of J. sabina.

Generally, the industrial extraction of most EOs uses large amounts of expensive solvents (n-hexane, alcohol) and it requires at least 50\% of the energy of the whole industrial process [40]. Future research should focus on improving the traditional steam and hydrodistillation processes and in the development of Green Extraction techniques. Green Extraction, which is a part of Green Chemistry, was defined as the extraction processes that will reduce energy consumption, allow the use of alternative solvents and renewable natural products, and ensure a safe and high-quality extract/product [40]. Our study investigated the EO fractions that were eluted at different distillation timeframe using water (as solvent) and low energy (following grinding of the plant material in water). The results from this study may contribute to the time and energy saving of EO extraction from the three juniper species, and help to obtain EO with desired composition. We hypothesized that capturing the EO segments during specific timeframes will generate EO fractions with different composition and antioxidant capacity. Therefore, in this study, the oil fractions that were eluted at different hydrodistillation timeframes and non-stop controls were compared for chemical profile and antioxidant capacity among each other within a species. The EO of each species (J. virginiana, J. excelsa, and J. sabina) were separately compared.

\section{Results}

\subsection{Essential oil (EO) Composition of J. virginiana, J. excelsa, and J. sabina}

The relationship between the EO content of J. virginiana and the concentrations of the constituents of EO with the different distillation times (DT) are illustrated in Figure 1. This figure also shows the fitted model that describes the relationship and that can be used for prediction purposes. The control treatment (non-stop 240 min distillation) resulted in 1.1\% EO in dried leaves (Table 1). 

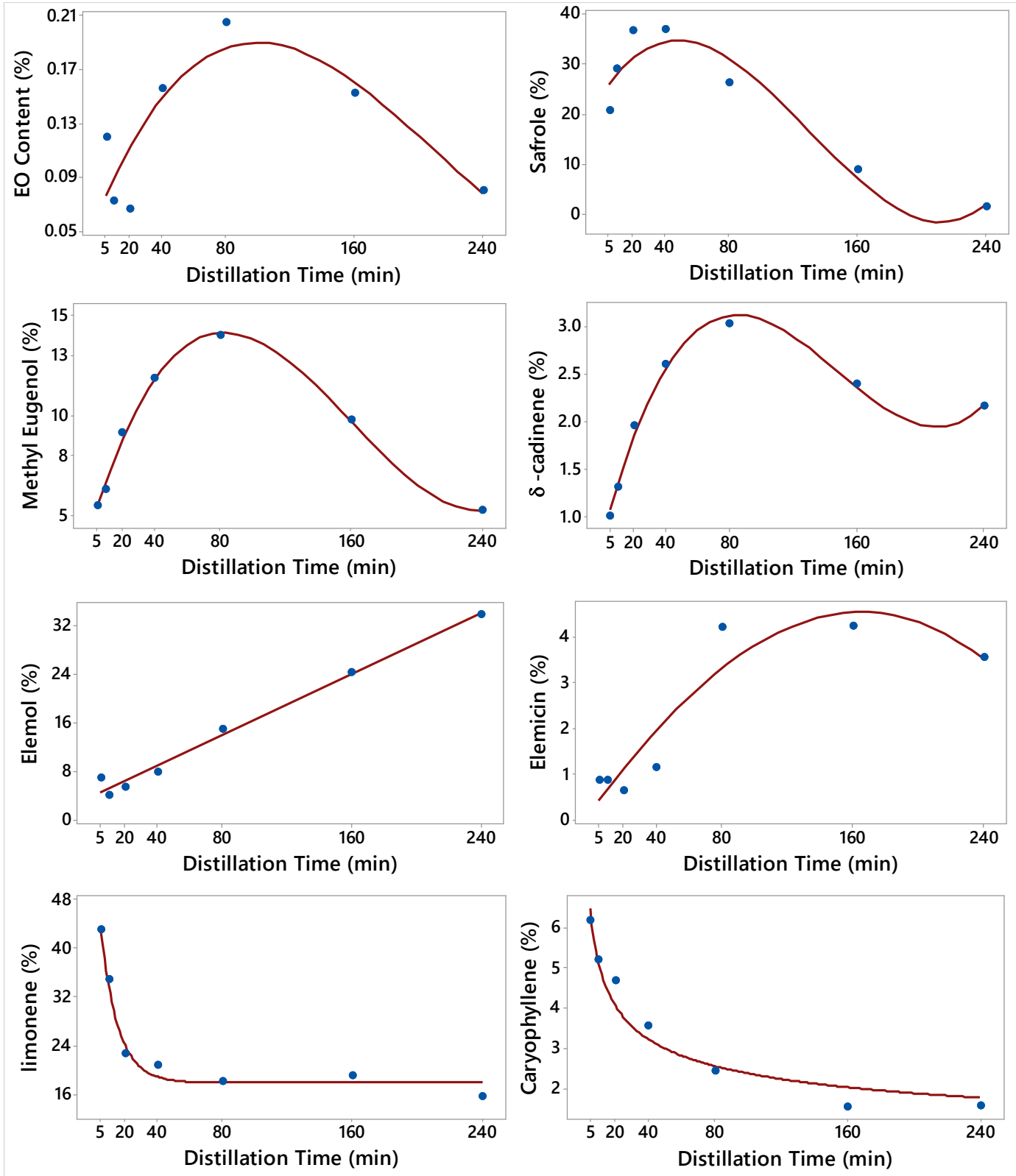

Figure 1. Plot of Distillation time vs. the essential oil (EO) content and the concentrations of 7 constituents along with the fitted Third order polynomial, Asymptotic, and Power regression models for Juniperus virginiana. The fitted models are: $\hat{Y}=0.06+0.003 D T-0.00002 D T^{2}+0.0000001 D T^{3}(\mathrm{EO}$ content), $\hat{Y}=23.64+0.496 D T-0.0064 D T^{2}+0.00002 D T^{3}$ (Safrole), $\hat{Y}=4.1+0.28 D T-0.002 D T^{2}+$ $0.000005 D T^{3}$ (Methyl Eugenol), $\hat{Y}=0.76+0.06 D T-0.0005 D T^{2}+0.000001 D T^{3}$ ( $\delta$-cadinene), $\hat{Y}=$ $3.99+0.125 D T$ (Elemol), $\hat{Y}=0.2+0.05 D T-0.00012 D T^{2}+0.0000001 D T^{3}$ (Elemicin), $\hat{Y}=17.9+$ $40.8(\operatorname{Exp}(-0.093 D T))$ (limonene), and $\hat{Y}=11.14 D T^{-0.336}$ (Caryophyllene). 
Table 1. Mean Juniperus virginiana essential oil (EO) content (\%), and the concentrations (\%) of limonene, pregeijerene $\mathrm{B}$, safrole, and methyl eugenol in the $\mathrm{EO}$ fractions obtained from the eight distillation times (DT).

\begin{tabular}{cccccc}
\hline DT (min) & EO Content (\%) & Limonene (\%) & Pregeijerene B (\%) & Safrole (\%) & Methyl Eugenol (\%) \\
\hline 5 & $0.12 \mathrm{~b}^{1}$ & $43.2 \mathrm{a}$ & $5.87 \mathrm{bc}$ & $20.60 \mathrm{bc}$ & $5.48 \mathrm{e}$ \\
10 & $0.07 \mathrm{~b}$ & $34.9 \mathrm{ab}$ & $9.30 \mathrm{a}$ & $29.00 \mathrm{ab}$ & $6.28 \mathrm{de}$ \\
20 & $0.07 \mathrm{~b}$ & $22.7 \mathrm{bc}$ & $8.45 \mathrm{a}$ & $36.50 \mathrm{a}$ & $9.12 \mathrm{c}$ \\
40 & $0.16 \mathrm{~b}$ & $20.7 \mathrm{bc}$ & $7.03 \mathrm{~b}$ & $36.79 \mathrm{a}$ & $11.85 \mathrm{ab}$ \\
80 & $0.20 \mathrm{~b}$ & $18.1 \mathrm{bc}$ & $6.59 \mathrm{~b}$ & $26.15 \mathrm{bc}$ & $13.97 \mathrm{a}$ \\
160 & $0.15 \mathrm{~b}$ & $19.1 \mathrm{bc}$ & $5.93 \mathrm{bc}$ & $8.94 \mathrm{~d}$ & $9.75 \mathrm{bc}$ \\
240 & $0.08 \mathrm{~b}$ & $15.6 \mathrm{c}$ & $4.80 \mathrm{c}$ & $1.45 \mathrm{~d}$ & $5.24 \mathrm{e}$ \\
Control & $1.12 \mathrm{a}$ & $26.9 \mathrm{bc}$ & $6.80 \mathrm{~b}$ & $19.08 \mathrm{c}$ & $8.53 \mathrm{~cd}$ \\
\hline
\end{tabular}

${ }^{1}$ Within each column, means followed by the same letter are not significantly different at the $5 \%$ level of significance.

In J. virginiana $\mathrm{EO}$, phenylpropene (Ph) was the second major chemical group, with safrole, methyl eugenol, and elemicin as major constituents (Tables 1 and 2). Overall, the elution of EO constituents that belonged to phenylpropene increased with DT and reached highest concentrations (49.8\%), in the 20-40 min fraction, and decreased afterward. The concentration of safrole (37\%) was also the highest in the 20-40 min fraction, the concentration of methyl eugenol was the highest in the 40-80 min fraction $(11.85 \%-13.97 \%)$, and the concentration of elemicin was highest in the $80-160$ min fraction $(4.2 \%)$ (Tables 1 and 2).

Table 2. Mean Juniperus virginiana concentrations (\%) of caryophyllene, $\delta$-cadinene, elemol, and elemicin in the essential oil fractions obtained from the 8 distillation times (DT).

\begin{tabular}{ccccc}
\hline DT (min) & Caryophyllene (\%) & ס-Cadinene (\%) & Elemol (\%) & Elemicin (\%) \\
\hline 5 & $6.17 \mathrm{a}^{1}$ & $1.01 \mathrm{~d}$ & $6.90 \mathrm{de}$ & $0.86 \mathrm{~b}$ \\
10 & $5.19 \mathrm{~b}$ & $1.31 \mathrm{~d}$ & $4.15 \mathrm{e}$ & $0.86 \mathrm{~b}$ \\
20 & $4.68 \mathrm{~b}$ & $1.95 \mathrm{c}$ & $5.43 \mathrm{de}$ & $0.65 \mathrm{~b}$ \\
40 & $3.55 \mathrm{c}$ & $2.60 \mathrm{ab}$ & $7.92 \mathrm{~d}$ & $1.16 \mathrm{~b}$ \\
80 & $2.42 \mathrm{de}$ & $3.03 \mathrm{a}$ & $14.90 \mathrm{c}$ & $4.20 \mathrm{a}$ \\
160 & $1.54 \mathrm{f}$ & $2.39 \mathrm{bc}$ & $24.30 \mathrm{~b}$ & $4.23 \mathrm{a}$ \\
240 & $1.56 \mathrm{ef}$ & $2.16 \mathrm{bc}$ & $33.84 \mathrm{a}$ & $3.55 \mathrm{a}$ \\
Control & $2.84 \mathrm{~cd}$ & $2.09 \mathrm{bc}$ & $15.05 \mathrm{c}$ & $3.41 \mathrm{a}$ \\
\hline
\end{tabular}

${ }^{1}$ Within each column, means followed by the same letter are not significantly different at the $5 \%$ level of significance.

The major chemical families of the J. virginiana EO constituents were monoterpene hydrocarbons $(\mathrm{MH})$, phenylpropene (PH), sesquiterpenes (bicyclic, monocyclic oxygenated ST), and polycyclic aromatic hydrocarbon $(\mathrm{PCH})$ (Table 3). During the first $5 \mathrm{~min}$ of the distillation, about $43 \%$ of the monoterpenes (e.g. limonene) were eluted. The quantity of the monoterpenes elution gradually decreased as the distillation time increased, and it reached the bottom (15.6\%) at $240 \mathrm{~min}$. Limonene concentration at the 0-5 min timeframe was 177\% higher than that eluted at 160-240 min timeframe fraction.

Table 3. Chemical families of Juniperus virginiana essential oil (EO) constituents as a function of their elution during hydrodistillation timeframes.

\begin{tabular}{ccccccccc}
\hline DT (min) & $\mathbf{0 - 5}$ & $\mathbf{5 - 1 0}$ & $\mathbf{1 0 - 2 0}$ & $\mathbf{2 0 - 4 0}$ & $\mathbf{4 0 - 8 0}$ & $\mathbf{8 0 - 1 6 0}$ & $\mathbf{1 6 0 - 2 4 0}$ & Control 0-240 \\
\hline MH\% & 43.2 & 34.9 & 22.7 & 20.7 & 18.1 & 19.1 & 15.6 & 26.9 \\
PCH\% & 1.01 & 1.31 & 1.95 & 2.60 & 3.03 & 2.39 & 2.16 & 2.09 \\
Ph & 26.94 & 36.14 & 46.27 & 49.8 & 44.32 & 22.91 & 10.24 & 31.02 \\
ST & 13.07 & 9.34 & 10.11 & 11.47 & 17.32 & 25.84 & 35.4 & 17.89 \\
\hline DT-Distillation time; & MH-Monoterpene & hydrocarbons; & PCH-polycyclic & aromatic & hydrocarbons; \\
Ph-phenylpropene; ST—-sesquiterpenes. & & & & &
\end{tabular}


Sesquiterpenes (ST, monocyclic oxygenated, bicyclic) were the third chemical group of J. virginiana EO constituents (Table 3). The elution of EO constituents that belonged to sesquiterpenes increased with the DT and it was the highest (35.4\%) in the 160-240 min oil fraction. The concentration of elemol (33.8\%) was the highest in this 160-240 min oil fraction (Table 2). The elution of caryophyllene was the greatest in the initial $5 \mathrm{~min}$ oil fraction and diminished in the subsequent DT fractions (Table 2). Polycyclic aromatic hydrocarbon $(\mathrm{PCH})(\delta$-cadinene) was identified in small quantities; its concentration increased from $1.01 \%$ in the $5 \mathrm{~min}$ fraction to $3.03 \%$ in $40-80 \mathrm{~min}$ fraction and then dropped again to $2.16 \%$ in the $160-240$ min fraction (Table 3 ).

Surely, the J. virginiana oil profile in this study was different from the constituents that were found in the J. virginiana wood oil reported in the literature. $\alpha$-cedrene, $\beta$-cedrene, thujopsene, cuparene, cedrol, and widdrol were the major constituents of wood oil of J. virginiana [41]. J. virginiana wood oil (also known as cedarwood oil) is used in a number of consumer products, due to its unique aroma and toxicity that repel and kill many pests [42]. The concentrations of limonene and caryophyllene were high at early DT and then gradually decreased in subsequent DT (Tables 1 and 2, Figure 1).

Figure 2 shows the relationship of the EO fractions of J. excelsa and the concentrations of its constituents with the distillation timeframes (DT). J. excelsa EO content (yield) was significantly higher during the first $5 \mathrm{~min}(0.29 \%)$ than in the DT onward 160-240 min (Table 4). Generally, monoterpenes ( $\alpha$-pinene, limonene) were the predominant group of the EO constituents (Tables 4 and 5).
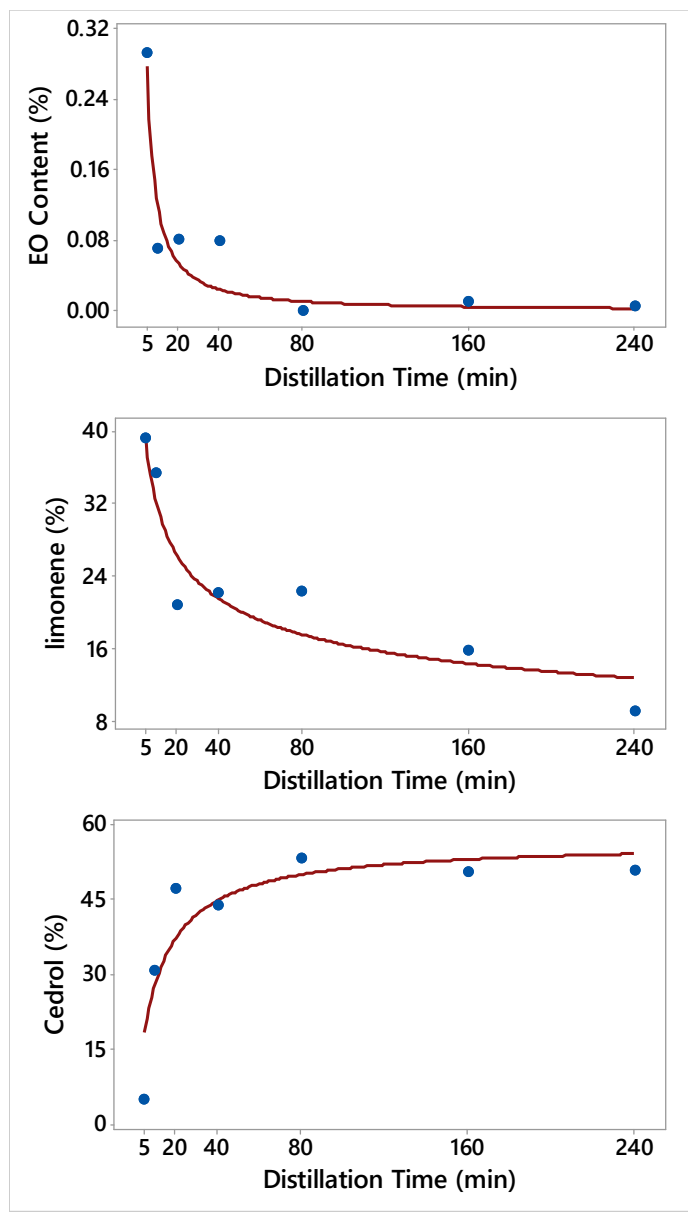

Figure 2. Plot of Distillation time vs. the essential oil (EO) content and the concentrations of 2 constituents along with the fitted Power and Michaelis-Menten nonlinear regression models for Juniperus excelsa. The fitted models are: $\hat{Y}=1.85 D T^{-1.175}$ (EO content), $\hat{Y}=63.4 D T^{-0.293}$ (limonene), and $\hat{Y}=\frac{56.42 D T}{10.48+D T}$ (Cedrol). 
Table 4. Mean Juniperus excelsa essential oil (EO) content (\%), and the concentrations (\%) of $\alpha$-pinene, limonene, and cedrol in the EO fractions that were obtained from the eight distillation timeframes (DT).

\begin{tabular}{ccccc}
\hline DT (min) & EO Content (\%) & $\alpha$-Pinene (\%) & Limonene (\%) & Cedrol (\%) \\
\hline 5 & $0.29 \mathrm{~b}$ & $34.4 \mathrm{a}$ & $39.2 \mathrm{a}$ & $4.9 \mathrm{~b}$ \\
10 & $0.07 \mathrm{c}$ & $19.7 \mathrm{ab}$ & $35.3 \mathrm{ab}$ & $30.6 \mathrm{ab}$ \\
20 & $0.08 \mathrm{c}$ & $11.1 \mathrm{~b}$ & $20.7 \mathrm{abc}$ & $47.1 \mathrm{a}$ \\
40 & $0.08 \mathrm{c}$ & $16.4 \mathrm{~b}$ & $22.1 \mathrm{abc}$ & $43.8 \mathrm{a}$ \\
80 & $0.00 \mathrm{c}$ & $24.7 \mathrm{ab}$ & $22.3 \mathrm{abc}$ & $53.1 \mathrm{a}$ \\
160 & $0.01 \mathrm{c}$ & $24.0 \mathrm{ab}$ & $15.8 \mathrm{bc}$ & $50.3 \mathrm{a}$ \\
240 & $0.01 \mathrm{c}$ & $13.9 \mathrm{~b}$ & $9.0 \mathrm{c}$ & $50.5 \mathrm{a}$ \\
Control & $0.93 \mathrm{a}$ & $35.6 \mathrm{a}$ & $30.6 \mathrm{abc}$ & $33.8 \mathrm{ab}$ \\
\hline
\end{tabular}

${ }^{1}$ Within each column, means followed by the same letter are not significantly different at the $5 \%$ level of significance.

Table 5. Chemical families of Juniperus excelsa essential oil (EO) constituents as a function of their elution during hydrodistillation timeframes.

\begin{tabular}{ccccccccc}
\hline DT (min) & $\mathbf{0 - 5}$ & $\mathbf{5 - 1 0}$ & $\mathbf{1 0 - 2 0}$ & $\mathbf{2 0 - 4 0}$ & $\mathbf{4 0 - 8 0}$ & $\mathbf{8 0 - 1 6 0}$ & $\mathbf{1 6 0 - 2 4 0}$ & Control 0-240 \\
\hline MH\% & 73.6 & 55.0 & 31.8 & 38.5 & 47.0 & 39.8 & 22.9 & 66.2 \\
ST & 4.9 & 30.6 & 47.1 & 43.8 & 53.1 & 50.3 & 50.5 & 33.8 \\
\hline
\end{tabular}

DT- Distillation time; MH - Monoterpene hydrocarbons; ST- sesquiterpenes.

Monoterpenes were eluted early in the distillation process 0-5 $\min (74 \%)$ (Table 5). The concentration of $\alpha$-pinene was highest at the first $5 \mathrm{~min}$ fraction $(34 \%)$ and in the control $(36 \%)$, and lowest at 10-20 min elution timeframe fraction (11\%); however, there was no consistent trend in EO composition changes with progressing timeframes (Table 4). Limonene eluted early in the distillation process, and therefore its concentration was higher in the fractions that were collected earlier than in the $80-160 \mathrm{~min}$ or in the 160-240 $\mathrm{min}$ fractions (Table 4, Figure 2). Limonene concentration increased by $336 \%$ when it was collected at 0-5 min timeframe when compared to the collection at the 160-240 min timeframe (Table 4). Oxygenated sesquiterpenes (OS) were the second most predominant chemical family of the J. excelsa EO constituents, with cedrol acting as the main one in this group. Cedrol started eluting after $5 \mathrm{~min}$ in the distillation process, and therefore its concentration was the lowest in the $0-5 \mathrm{~min}$ fraction (4.9\%). The concentration of cedrol increased by at least six-folds from 5-10 min DT (30.6\%) onward when compared to $0-5 \min$ DT $(4.9 \%)$. The concentration of cedrol (53\%) was the highest in the 40-80 min oil fraction (Table 4).

The relationships between the EO of J. sabina and its constituents, and DT, are illustrated in Figure 3. The fitted Power (convex) and Asymptotic models that describe these relationships are also shown in Figure 3. The distillation timeframes for capturing the oil fractions for J. sabina were selected to be different from those of J. virginiana and J. excelsa in this study based on preliminary studies. The main chemical group of J. sabina EO was the monoterpenes (hydrocarbons and oxygenated) (Tables 6 and 7). A significant portion of the monoterpene hydrocarbons ( $\mathrm{MH}, 90.5 \%)$ in J. sabina was eluted very early in the distillation process that constituted the 0-3 min fraction (Table 8). As the name suggests, sabinene was the major constituent of the MH in J. sabina EO (Table 6). Sabinene was eluted early in the distillation process (Figure 3). Therefore, the concentration of sabinine was greater in the 0-3 min fraction $(80 \%)$ and it decreased in the fractions that were collected later in the distillation process (26.6\%) (Table 6). Similarly, the $0-3 \mathrm{~min}$ fraction had higher concentrations of $\alpha$-pinene, $\beta$-pinene, $\alpha$-thujene, and limonene when compared to fractions that were collected at the late elution timeframes (after $3 \mathrm{~min}$ ) (Figure 3, Tables 6 and 7).

The concentration of citronellic acid was the lowest during the first 3 min elution (2.4\%), peaked during the $3-5 \min (11 \%)$, and then decreased with subsequent DT. 

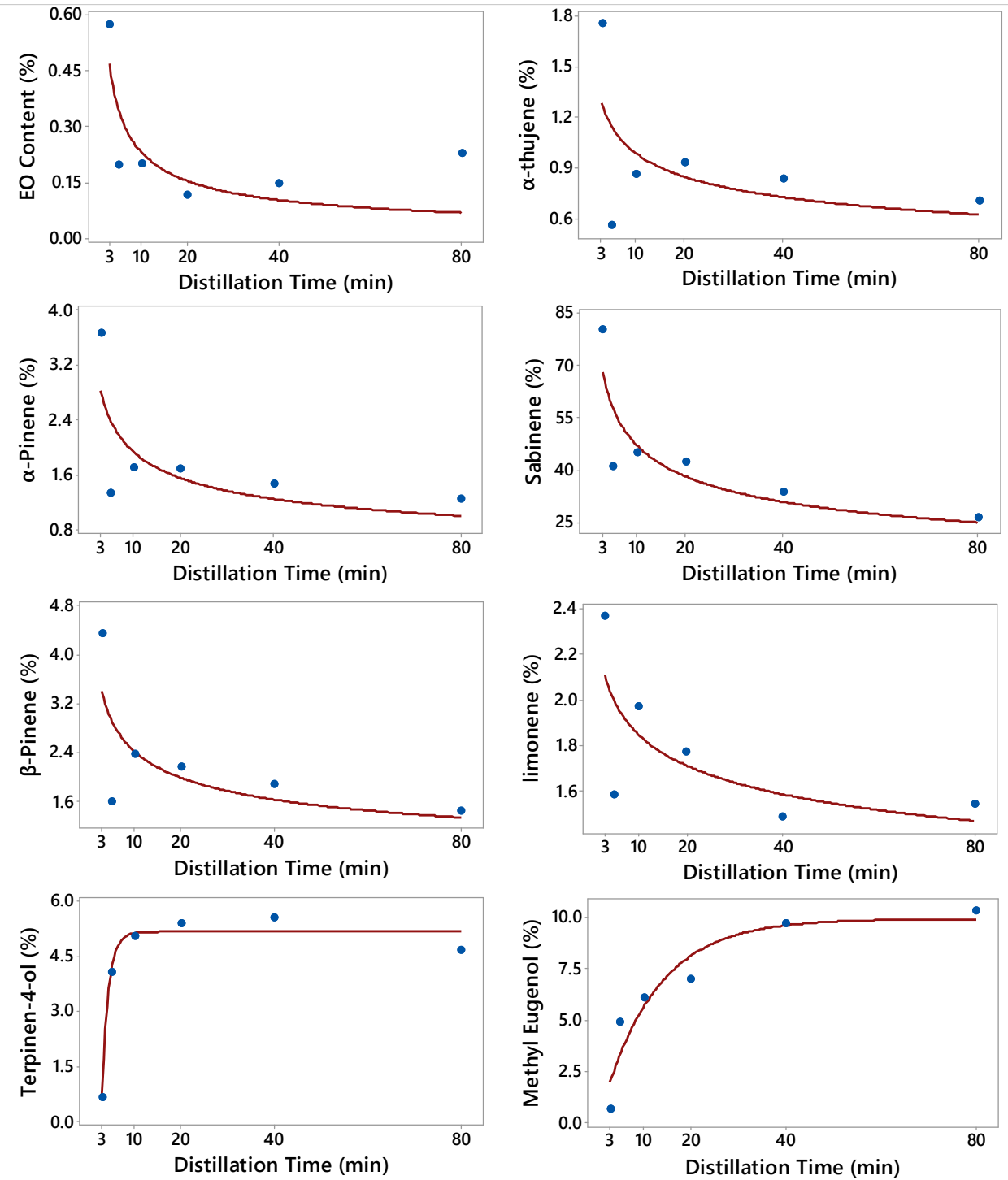

Figure 3. Plot of Distillation time vs. the essential oil (EO) content and the concentrations of 7 constituents along with the fitted Power (convex) and Asymptotic (convex) nonlinear regression models for Juniperus sabina. The fitted models are: $\hat{Y}=0.89 D T^{-0.59}$ (EO content), $\hat{Y}=1.64 D T^{-0.22}$ ( $\alpha$-thujene), $\hat{Y}=4.0 D T^{-0.31}$ ( $\alpha$-pinene), $\hat{Y}=94.8 D T^{-0.3}$ (Sabinene), $\hat{Y}=4.67 D T^{-0.28}$ ( $\beta$-pinene), $\hat{Y}=2.38 D T^{-0.11}$ (limonene), $\hat{Y}=5.16-36.3(\operatorname{Exp}(-0.696 D T))($ Terpinen-4-ol), and $\hat{Y}=9.94-10.3(\operatorname{Exp}(-0.087 D T))$ (Methyl Eugenol).

Table 6. Mean Juniperus sabina essential oil (EO) content (\%), and the concentrations (\%) of $\alpha$-thujene, $\alpha$-pinene, sabinene, and $\beta$-pinene in the EO fractions obtained from the seven distillation timeframes (DT).

\begin{tabular}{cccccc}
\hline DT (min) & EO Content (\%) & $\alpha$-Thujene (\%) & $\alpha$-Pinene (\%) & Sabinene (\%) & $\beta$-Pinene (\%) \\
\hline 3 & $0.57 \mathrm{~b}^{1}$ & $1.75 \mathrm{a}$ & $3.67 \mathrm{a}$ & $80.1 \mathrm{a}$ & $4.36 \mathrm{a}$ \\
5 & $0.19 \mathrm{c}$ & $0.55 \mathrm{~b}$ & $1.33 \mathrm{~b}$ & $41.2 \mathrm{bc}$ & $1.60 \mathrm{bc}$ \\
10 & $0.19 \mathrm{c}$ & $0.85 \mathrm{~b}$ & $1.70 \mathrm{~b}$ & $45.1 \mathrm{bc}$ & $2.38 \mathrm{bc}$ \\
20 & $0.11 \mathrm{c}$ & $0.93 \mathrm{~b}$ & $1.69 \mathrm{~b}$ & $42.4 \mathrm{bc}$ & $2.18 \mathrm{bc}$ \\
40 & $0.14 \mathrm{c}$ & $0.82 \mathrm{~b}$ & $1.48 \mathrm{~b}$ & $33.7 \mathrm{c}$ & $1.88 \mathrm{bc}$ \\
80 & $0.22 \mathrm{c}$ & $0.70 \mathrm{~b}$ & $1.25 \mathrm{~b}$ & $26.6 \mathrm{c}$ & $1.45 \mathrm{c}$ \\
Control & $1.43 \mathrm{a}$ & $1.36 \mathrm{ab}$ & $2.39 \mathrm{ab}$ & $61.4 \mathrm{ab}$ & $3.67 \mathrm{ab}$ \\
\hline
\end{tabular}

${ }^{1}$ Within each column, means followed by the same letter are not significantly different at the $5 \%$ level of significance. 
Table 7. Mean Juniperus sabina concentration (\%) of limonene, terpinen-4-ol, citronellic acid methyl ester, and methyl eugenol in the essential oil fractions obtained from the seven distillation timeframes (DT).

\begin{tabular}{ccccc}
\hline DT (min) & Limonene (\%) & Terpinen-4-ol (\%) & Citronellic Acid Methyl Ester (\%) & Methyl Eugenol (\%) \\
\hline 3 & $2.37 \mathrm{a}^{1}$ & $0.65 \mathrm{c}$ & $2.36 \mathrm{c}$ & $0.68 \mathrm{~b}$ \\
5 & $1.58 \mathrm{ab}$ & $4.05 \mathrm{ab}$ & $11.00 \mathrm{a}$ & $4.87 \mathrm{ab}$ \\
10 & $1.97 \mathrm{ab}$ & $5.03 \mathrm{a}$ & $8.25 \mathrm{ab}$ & $6.08 \mathrm{ab}$ \\
20 & $1.77 \mathrm{ab}$ & $5.36 \mathrm{a}$ & $6.23 \mathrm{bc}$ & $6.97 \mathrm{a}$ \\
40 & $1.49 \mathrm{~b}$ & $5.54 \mathrm{a}$ & $5.24 \mathrm{bc}$ & $9.69 \mathrm{a}$ \\
80 & $1.54 \mathrm{~b}$ & $4.65 \mathrm{ab}$ & $4.31 \mathrm{c}$ & $10.32 \mathrm{a}$ \\
Control & $2.06 \mathrm{ab}$ & $2.71 \mathrm{bc}$ & $3.85 \mathrm{c}$ & $4.70 \mathrm{ab}$ \\
\hline
\end{tabular}

${ }^{1}$ Within each column, means followed by the same letter are not significantly different at the $5 \%$ level of significance.

Table 8. Chemical families of Juniperus sabina essential oil (EO) constituents as a function of their elution during hydrodistillation timeframes.

\begin{tabular}{cccccccc}
\hline DT (min) & $\mathbf{0 - 3}$ & $\mathbf{3 - 5}$ & $\mathbf{5 - 1 0}$ & $\mathbf{1 0 - 2 0}$ & $\mathbf{2 0 - 4 0}$ & $\mathbf{4 0 - 8 0}$ & Control 0-80 \\
\hline MH\% & 90.5 & 45.7 & 51.2 & 48.0 & 38.6 & 30.8 & 69.5 \\
PCH\% & 2.40 & 4.60 & 5.90 & 6.29 & 6.36 & 5.35 & 4.1 \\
Ph & 0.68 & 4.87 & 6.08 & 6.97 & 10.0 & 10.3 & 4.7 \\
\hline DT-Distillation & time; & MH-Monoterpene & hydrocarbons; & PCH-polycyclic aromatic \\
hydrocarbons; Ph—phenylpropene.
\end{tabular}

Methyl eugenol was the major constituent of the third chemical group, phenylpropanoids of J. sabina EO. The concentration of methyl eugenol was the lowest in the 0-3 min fraction (Figure 3, Table 7) and it increased in the subsequent timeframes. Terpinen-4-ol was the major constituent of the oxygenated monoterpenes (OS) chemical group, and its concentrations increased to around $5.5 \%$ in the $20-40$ min fraction.

\subsection{Antioxidant Capacity of J. virginiana, J. excelsa, and J. sabina}

The in vitro anti-oxidant capacity of J. virginiana, J. excelsa, and J. sabina was found to be affected by the DT (Table 9), thus confirming our hypothesis. The oxygen radical absorbance capacity (ORAC) value of $J$. virginiana was the highest at the 5-10 min time fraction (329 $\mu \mathrm{M}$ Trolox Equiv/per $\mathrm{g}$ oil) and the lowest at the 40-160 min timeframe (184 $\mu \mathrm{M}$ Trolox Equiv/per g oil) (Table 9). Similarly, the ORAC value of $J$. sabina was the highest in the 3-10 min oil fraction (56 $\mu \mathrm{M}$ Trolox Equiv/per g oil) and the lowest at the 10-20 min oil fraction ( $22 \mu \mathrm{M}$ Trolox Equiv/per g oil). The significant trend with DT was observed for the ORAC value of J. excelsa, indicating that the in vitro antioxidant capacity of $J$. excelsa drastically decreases with subsequent elution (Table 9). However, greater anti-oxidant capacity from the EO of J. excelsa can be captured if the EO is collected in $240 \mathrm{~min}$, i.e., 0-240 min non-stop DT (104 $\mu \mathrm{M}$ Trolox Equiv/per g oil) (Table 9).

Table 9. Mean oxygen radical absorbance capacity (ORAC) value (uM Trolox Equiv/per g oil) in Juniperus virginiana, J. excelsa, and J. sabina obtained from different distillation times (DT).

\begin{tabular}{cccccc}
\hline DT (min) & J. virginiana ORAC & DT (min) & J.excelsa ORAC & DT (min) & J. sabina ORAC \\
\hline 5 & $214 \mathrm{~b}$ & 5 & $68.2 \mathrm{~b}$ & 3 & $52.8 \mathrm{ab}$ \\
10 & $329 \mathrm{a}$ & 80 & $10.3 \mathrm{c}$ & 10 & $55.9 \mathrm{a}$ \\
40 & $227 \mathrm{~b}$ & 160 & $6.4 \mathrm{~cd}$ & 20 & $22.3 \mathrm{c}$ \\
160 & $184 \mathrm{~b}$ & 240 & $3.4 \mathrm{~d}$ & 40 & $35.8 \mathrm{abc}$ \\
240 & $205 \mathrm{~b}$ & Control & $104.1 \mathrm{a}$ & 80 & $29.7 \mathrm{bc}$ \\
Control & $193 \mathrm{~b}$ & - & - & Control & $28.2 \mathrm{bc}$ \\
\hline
\end{tabular}

${ }^{1}$ Within each species, ORAC means followed by the same letter are not significantly different at the $5 \%$ level of significance. 


\section{Discussion}

This is the first report on J. virginiana, J. excelsa, and J. sabina EO fractions that were generated in different timeframes following a grinding of the material to significantly speed up the extraction. Overall, the results confirmed the hypothesis of this study that capturing the EO segments during specific timeframes will generate EO fractions with different composition and antioxidant capacity (ORAC values).

\subsection{Essential Oil (EO) Composition of J. virginiana, J. excelsa, and J. sabina}

The EO yield (content) of the leaves of J. virginiana at different DT frames that were used in this study was higher than the J. virginiana EO yield that was reported by Gawde et al. [28,29], who recovered $0.17 \%$ of $\mathrm{EO}$ after $90 \mathrm{~min}$ of steam distillation, whereas J. virginiana $\mathrm{EO}$ yield in this study was $1.12 \%$ (in the control). Therefore, this study revealed that the grinding of J. virginiana leaves in water prior to extraction with subsequent hydrodistillation for 240 min can recover $>$ six fold of EO as compared to the 90 min steam distillation without grinding, as in the study by Gawde et al. [28]. In the study of Cantrell et al. [16], the J. virginiana 'Grey Owl' and J. virginiana 'Canaertii' the EO yield was $0.5-0.65 \%$ and $0.04-0.3 \%$, respectively, demonstrating the range of EO yield in this species.

The specific composition of the EO fractions that were eluted at different hydrodistillation timeframes can be attributed to the different boiling points of the respective EO constituents $[43,44]$. The EOs are complex products and they include a number of constituents with different molecular weights and diverse temperature separation points. In the initial minutes of the distillation, the most volatile EO constituents, such as monoterpenes, are eluted. Limonene (monoterpene) and caryophyllene (sesquiterpenes) eluted at early DT due to their low boiling points (limonene at $176^{\circ} \mathrm{C}$ and caryophyllene at $116^{\circ} \mathrm{C}$ ), whereas elemol increased in late timeframe fractions due to its high boiling point $\left(290^{\circ} \mathrm{C}\right)$.

The concentration of limonene that was collected at the first $5 \mathrm{~min}$ in this study was 2.4 and 16.6 times greater than that reported by Dunford et al. [45] and Gawde et al. [29] from Oklahoma and Mississippi, USA, respectively. The former authors had used hydrodistillation for $6 \mathrm{~h}$, while the latter researchers had used steam distillation for $1.5 \mathrm{~h}$. In addition to the extraction methods implied, the ecotype of plant affects the composition of EO [46]. However, it is evident from this study that the highest concentrations of the major constituents of J. virginiana leaves (limonene and safrole) can be collected with minimal time and energy with this method of prior grinding of the material in water. Limonene, safrole, and elemol were the major constituents of J. virginiana in this study, and the overall oil profile was similar to some of the J. virginiana oils in the samples that were collected from 49 locations in the United States [16]. However, the J. virginiana oil in this study would not fit any of the 10 chemotypes that were identified by the latter authors. Therefore, we could classify J. virginiana that was used in this study as another chemotype of J. virginana, namely limonene-safrole-elemol chemotype.

In this study, the major chemical families of $J$. excelsa control oil included monoterpene hydrocarbons ( $\mathrm{MH}$, such as 35.6\% $\alpha$-pinene and 30.6\% limonene) and oxygenated sesquiterpenes (OS, $33.8 \%$ cedrol). The concentration of $\alpha$-pinene in this study was within the range for J. excelsa EO that was reported by Sanjani et al. [24], however, the concentration of limonene in the same report was only 1.5-2.1\%, and no cedrol was reported, which is difficult to explain. Unlu et al. [22], reported $\alpha$-pinene $(55.5 \%), \alpha$-cedrol $(7.7 \%)$, sabinene $(3.5 \%)$, and verbenone $(2.4 \%)$ as the main constituents of $J$. excelsa galbuli EO.

Also in this study, higher concentrations of the major constituents of the J. excelsa EO eluted in significantly shorter distillation times than in the study by Emami et al. [14]. It took four hours of distillation for Emami et al. [14] to collect J. excelsa oil with 32\% $\alpha$-pinene, 4.4\% limonene, and 13\% cedrol when compared to this study, where most of the oil was eluted in the first $5 \mathrm{~min}$. In this study, cedrol in the 5-10 min fraction was already 31\%. Similarly, sabinine, a major constituent of the EO of J. sabina, also eluted at a significantly higher concentration in the first 3 min than in the subsequent DT. Differences may be attributed to grinding of the plant material prior to the EO extraction in this 
study. The results from this study can be used to specify the optimum distillation time and to avoid the unnecessarily long DT (if the material is ground prior to the EO extraction). J. excelsa EO with high concentrations of $\alpha$-pinene and limonene and low concentration of cedrol can be obtained in the first $5 \mathrm{~min}$ DT. Conversely, if greater than $50 \%$ cedrol is desirable, then this can be achieved by removing the first 5 min eluted fraction. Cedrol is a well-known and widely used aromatic ingredient in various consumer products, as in perfumery and cosmetics, shampoos, soaps, cleaners and detergents [47], due to its mild woody cedarwood-like sweet aroma with a sandalwood note. In addition, cedrol has shown a preventive effect against chemo-therapy induced alopecia in mice [48] and it has shown insecticidal properties [31,47], it has a potential to be used for preventing or treating autoimmune diseases [49]. Worldwide consumption/demand for cedrol has been reported to be 1-10 metric tonnes per year [50].

In this study, sabinene was the main J. sabina EO constituent and it belongs to the monoterpenes group. The control J. sabina oil had $61 \%$ sabinene. This study demonstrated that a high sabinene EO fraction ( $80 \%$ sabinene) could be obtained in the first 0-3 min hydrodistillation time, following a grinding of plant material in water. The concentration of sabinene in this study was higher than the values reported in the literature, whereas the concentration of the other monoterpene constituents, such as $\alpha$-thujene, $\alpha$-pinene, $\beta$-pinene, limonene, terpinen-4-ol, and the phenylpropanoids citronellic acid ME and methyl eugenol, were generally lower.

In a study with male and female plants J. sabina leaves, Asili et al. [51] reported sabinene (22 and $24 \%$ ), $\alpha$-pinene (15 and 6\%), and myrcene (7 and 8\%), respectively. Fournier et al. [52], in a study of $J$. sabina cultivars and wild type, reported $24 \%$ sabinene in the wild type, and $18 \%, 18 \%$, and $41 \%$ in three J. sabina cultivars. In the same study, sabinyl acetate was $45.5 \%$ in the EO of the wild type, and 53\%, 19\%, and $38 \%$ in the three J. sabina cultivars, respectively. The authors commented that sabinene in previous studies varied from 26 to $42 \%$ of the oil. However, the data that was provided seemed to be from a single rep and it was lacking statistical analyses. Apparently, the J. sabina chemical composition and the concentration of sabinene widely vary, which suggests the presence of chemotypes. We anticipate more research on J. sabina accessions and the identification of various chemotypes. From practical perspective, high sabinene ( $80 \%$ ) low methyl eugenol J. sabina EO fraction can be obtained if the oil is sampled in the first $3 \mathrm{~min}$ of the distillation process. In a recent ruling, the United States Food and Drug Administration (FDA) [53] removed six synthetic flavoring substances, including methyl eugenol, from the food additives list, because experiments with high intake doses may cause cancer in laboratory animals. Although this ruling did not affect "natural flavors" counterparts that were extracted from plants, we expect the industry to diminish/reduce the use of methyl eugenol and/or reduce its concentration in food products. Therefore, we anticipate increased market demand for $\mathrm{EO}$ with reduced methyl eugenol content.

\subsection{Antioxidant Capacity of J. virginiana, J. excelsa, and J. sabina Essential Oils (EO)}

Essential oils have been reported to possess anticancer, antinociceptive, antiphlogistic, antiviral, antibacterial, and antioxidant properties [54]. Studies that seek to reveal the antioxidant potential of natural products, including EO, are numerous, although the in vitro antioxidant activity assays have a number of drawbacks and do not allow for a comparison of the results [55,56]. Furthermore, it is now clear that the term 'antioxidant' is primarily a marketing tool. The results from in vitro antioxidant capacity assays have little if any relevance to the complexity of the interactions of EO in biological systems. The higher antioxidant capacity of some natural products that were observed in vitro cannot be readily correlated to a potential positive health effect on humans, leading some scientists to suggest the banning of these types of assays [56], and some scientific journals to declare that they would no longer review manuscripts describing in vitro antioxidant measurements [55].

Generally, the in vitro antioxidant potential of the EO depends on its composition and it is determined by the interaction between its constituents [57]. It is known that phenols and secondary metabolites with conjugated double bonds usually exhibit significant in vitro antioxidant activity [58]. Secondary metabolites with conjugated double bonds also include monoterpenes and sesquiterpenes 
in the EO. However, it is impossible to model the specific contribution of each EO constituent towards the overall in vitro antioxidant capacity of a given fraction. Further experiments would be needed to assess the observed in vitro antioxidant capacity of individual EO constituents, because, in many cases, there is synergy between the various EO constituents with respect to their bioactivity [57,59].

Overall, in this study, the higher in vitro antioxidant capacity was exhibited by the 3-10 min oil fraction in J. sabina and by the 5-10 min oil fraction in J. virginiana. In J. sabina, monoterpenes ( $\alpha$-pinene, $\beta$-pinene, limonene) and sesquiterpenes ( $\alpha$-thujene, sabinene) predominated in this fraction. In $J$. virginiana, limonene and caryophyllene phenylpropene (safrole), branched unsaturated hydrocarbons (Pregeijerene), predominated in this time fraction. Cantrell et al. [16] reported a difference in in vitro antioxidant activity on EO of J. virginiana, due to differences in chemotypes. The antioxidant capacity of the EO may also change with the change in the ratio of various volatile and non-volatile compounds [60]. Zheljazkov et al. [61] found the relation of composition of EO with the in vitro antioxidant capacity of J. sabina and J. excelsa; and, Emami et al. [14] also observed variation in the antioxidant capacity of the EO of J. excelsa with the methods of the antioxidant assays employed. Our study revealed that in vitro antioxidant capacity depends on the specific composition of the oil fraction that was captured in distinct timeframe, and hence support our hypothesis. However, the results from the in vitro antioxidant capacity of EO fractions may only be indicative of differences in some kind of activity between the fractions, and it must not be correlated to any potential health effects of a specific EO fraction.

\section{Materials and Methods}

\subsection{Plant Material}

Plant material of Juniperus excelsa Bieb., Juniperus sabina L., and Juniperus virginiana L. (branches not thicker than $10 \mathrm{~mm}$ with leaves) was collected in the autumn of 2017 from natural populations (of the J. sabina and J. excelsa) in Bulgaria. The collected biomass samples were immediately transferred and then dried in an aerated shady place for a month until a constant weight, before oil was isolated. The leaves were carefully separated from branches in order to avoid EO losses. Therefore, in this study, only the leaves of the three junipers were distilled for EO extraction. The collection of juniper biomass samples was made from the following habitats: J. excelsa biomass samples were collected from the natural habitat near the town of Kresna, Bulgaria, along the road at $41^{\circ} 046^{\prime} 00.1^{\prime \prime} \mathrm{N} ; 23^{\circ} 08^{\prime} 55.5^{\prime \prime} \mathrm{E}$. The $J$. virginiana biomass samples were collected along the road from the town of Blagoevgrad to Simitli, Bulgaria, collected at $41^{\circ} 51^{\prime} 17.57^{\prime \prime} \mathrm{N}, 23^{\circ} 07^{\prime} 48.72^{\prime \prime} \mathrm{E}$. It was assumed that the specific J. virginiana tree was either an escapee or planted as ornamental in that area. The J. sabina biomass samples were collected from natural habitat near Beli Iskar, Bulgaria, at $42^{\circ} 15^{\prime} 46^{\prime \prime} .3^{\prime \prime} \mathrm{N}, 23^{\circ} 32^{\prime} 26^{\prime \prime} .7^{\prime \prime} \mathrm{E}$. The voucher specimens of J. excelsa Bieb., J. sabina L., and J. virginiana L. (small branches with needles) were deposited at the Herbarium of the Agricultural University, Plovdiv, Bulgaria (SOA) [62].

\subsection{Essential Oil (EO) Extraction of the Juniper Leaves}

The EO of the leaves was extracted via hydrodistillation in 2-L distillation units (Laborbio Ltd. Sofia, Bulgaria, laborbio.com) at the Research Institute for Roses and Medicinal Plants in Kazanluk, Bulgaria. Each extraction was performed in three replicates. Research has shown that the juniper EO may continue to elute even after 10-14 h of steam distillation [18,25]. Therefore, to speed up the hydrodistillation process, the samples were ground in water prior to the extraction. Samples of $100 \mathrm{~g}$ of dried leaves plus 1.2 L of water were placed in a kitchen food processor (blender) and ground for $48 \mathrm{~s}$ immediately prior to the extraction. Our preliminary studies demonstrated that grinding juniper leaves in water greatly reduces the time and energy necessary for the EO extraction, and also eliminates EO losses due to the potential rapid volatilization during the grinding process.

The beginning of the distillation in each replicate was noted when the first droplet of EO dropped from the condenser into the collecting unit of the apparatus. The EO fractions were captured at 
different timeframes: 0-5; 5-10; 10-20; 20-40; 40-80; 80-160; 160-240; and, 0-240 non-stop control for J. virginiana and J. excelsa and $0-3 ; 3-5 ; 5-10 ; 10-20 ; 20-40 ; 40-80$; and, 0-80 min non-stop control for J. sabina. These timeframes were established based on preliminary experiments. The eluted oil fractions were captured without interrupting the hydrodistillation process, resulting in EO fractions that represented the eluted oil constituents within these timeframes. The oil was transferred in 2-mL vials and placed in a freezer. Later, the oil was separated from water and measured on an analytical scale and kept in a freezer again until the oil was analyzed. Here, we report the oil content (yield) based on weight.

\subsection{Gas Chromatography Mass Spectrometry Flame Ionization Detection (GC-MS-FID) of essential oil (EO) and Distillation Fractions}

The constituents were identified and quantified in juniper essential oil and distillation fractions. Oil samples were analyzed by GC-MS-FID on an Agilent 7890A GC system (Santa Clara, CA, USA) that was equipped with a Agilent 5975C inert XL MSD with triple axis detector and an Agilent 7693 autosampler. DB-5 fused silica capillary column $(30 \mathrm{~m} \times 0.25 \mathrm{~mm}$, with a film thickness of $0.25 \mu \mathrm{m})$ was used and operated using the following conditions: injector temperature, $240{ }^{\circ} \mathrm{C}$; column temperature, $60-240$ at $3{ }^{\circ} \mathrm{C} / \mathrm{min}$, and then held at $240{ }^{\circ} \mathrm{C}$ for $5 \mathrm{~min}$; carrier gas, He; injection volume, $1 \mu \mathrm{L}$ (split ratio 25:1); the FID temperature was $300{ }^{\circ} \mathrm{C}$. Post-column splitting was performed so that $50 \%$ of sample proceeds to FID and 50\% to mass spectrometry (MS) detection. The MS mass range was from $\mathrm{m} / \mathrm{z} 50$ to 550; filament delay, $3.5 \mathrm{~min}$; source temperature, $230{ }^{\circ} \mathrm{C}$; and, quad temperature, $150{ }^{\circ} \mathrm{C}$.

Kovat analysis identified the compounds limonene, safrole, methyl eugenol, caryophyllene, $\alpha$-pinene, cedrol, sabinene, $\beta$-pinene, terpinen-4-ol, and methyl eugenol in oil samples [63], comparison of retention times and mass spectra with authentic standards, and a comparison of mass spectra with those that were reported in the NIST mass spectra database. Standards of R-(+)-limonene, safrole, methyl eugenol, caryophyllene, $\alpha$-pinene, cedrol, sabinene, $\beta$-pinene, terpinen-4-ol, and methyl eugenol were purchased from Sigma-Aldrich (St. Louis, MO, USA). Compounds pregeijerene B, $\alpha$-thujene, $\delta$-cadinene, elemol, and elemicin were identified in oil samples by Kovat analysis and a comparison of mass spectra with those that were reported in the NIST mass spectra database and/or comparison of mass spectra with those reported by Adams et. al., 2007 [63]. Citronellic acid methyl ester was identified by a comparison of mass spectra with those that were reported in the NIST mass spectra database and by a comparison of retention time and mass spectra data with an authentic standard that was synthesized in our laboratory. Citronellic acid methyl ester was produced by methylation of (S)-(-)-citronellic acid (Sigma-Aldrich (St. Louis, MO, USA) using diazomethane.

Compounds were quantified by performing area percentage calculations based on the total combined FID area. For example, the area for each reported peak was divided by the total integrated area from the FID chromatogram from all reported peaks and multiplied by 100 to arrive at a percentage. The percentage of a peak is a percentage relative to all other constituents that were integrated in the FID chromatogram.

\subsection{Diazomethane Generation and Citronellic Acid Methyl Ester Synthesis}

An Aldrich Mini Diazald apparatus was used for the production of $\mathrm{CH}_{2} \mathrm{~N}_{2}$ in ether. Briefly, $2.5 \mathrm{~g}$ of $\mathrm{KOH}$ was dissolved in $4 \mathrm{~mL}$ of deionized $\mathrm{H}_{2} \mathrm{O}$ and then placed in the reaction vessel, followed by the addition of $5 \mathrm{~mL}$ of EtOH. A separatory funnel containing $2.5 \mathrm{~g}$ of diazald dissolved in $22.5 \mathrm{~mL}$ of ether was placed above the reaction vessel. The reaction vessel was warmed to $68{ }^{\circ} \mathrm{C}$ using a $\mathrm{H}_{2} \mathrm{O}$ bath, followed by the drop wise addition of the diazald soln. over a period of $40 \mathrm{~min}$. The receiving flask and condenser cold finger were cooled using a dry ice/acetone bath. The co-distilled $\mathrm{CH}_{2} \mathrm{~N}_{2}$ in ether soln. was stored in sealed vials at $-20{ }^{\circ} \mathrm{C}$ until needed.

$2.5 \mathrm{mg}$ of (S)-(-)-citronellic acid in $0.5 \mathrm{~mL}$ of methylene chloride was treated at r.t. with a soln. of $0.5 \mathrm{~mL}$ of $\mathrm{CH}_{2} \mathrm{~N}_{2}$ in the ether prepared above. The soln. was placed in a laboratory fume hood 
overnight to complete the reaction, allowed for evaporation of solvent and $\mathrm{CH}_{2} \mathrm{~N}_{2}$, and the sample was then redissolved in $\mathrm{Et}_{2} \mathrm{O}$ for $\mathrm{GC}$ analysis.

\subsection{Methodology for Antioxidant Capacity Evaluation of the Essential Oils (EO) Fractions from the Three Juniper Species}

The EO fractions from the three junipers were analyzed for antioxidant capacity using the oxygen radical absorbance capacity (ORAC oil) at the University of Nebraska-Lincoln, Small Molecule Analysis Laboratory, using the method that was developed by Huang et al. $[64,65]$ and as described previously [61]. Briefly, Trolox, (6-hydroxy-2,5,7,8-tetramethylchroman-2-carboxylic acid), which is a polar derivative of Vitamin E, was used as a standard, and the results were reported as $\mu$ mole Trolox $\mathrm{g}^{-1}$. Each replicate of the EO from the three junipers and all DTs were analyzed in triplicate, and the averages of these three readings were used for the statistical analysis, as described below.

\subsection{Statistical Analyses}

The effect of distillation time (DT) on EO content and the concentration of constituents were determined for each of three juniper species (J. virginiana, J. excelsa, and J. sabina) in Bulgaria using a one-way analysis of variance. For J. virginiana, the constituents were limonene, pregeijerene B, safrole, methyl eugenol, caryophyllene, $\delta$-cadinene, elemol, and elemicin. For J. excelsa, the constituents were $\alpha$-pinene, limonene, and cedrol. For J. sabina, the constituents were $\alpha$-thujene, $\alpha$-pinene, sabinene, $\beta$-pinene, limonene, terpinen-4-ol, citronellic acid methyl ester, and methyl eugenol. For each species, the effect of DT on ORAC value (uM Trolox Equiv/per g oil) was also determined.

For each response variable, the validity of model assumptions was verified by examining the residuals, as described in Montgomery [66]. Since the effect of DT was significant ( $p$-value $<0.05$ ) on all response variables, multiple means comparison was completed using Tukey's Multiple Range test at the $5 \%$ level of significance and letter groupings were generated. The analysis was completed using the GLM Procedure of SAS [67].

For J. virginiana, the most appropriate regression model that describes the relationship between DT and EO content, concentrations of safrole, methyl eugenol, $\delta$-cadinene, elemol, and elemicin was a third order polynomial (Equation (1)), the model that describes the relationship between DT and the concentration of limonene was Asymptotic (convex) (Equation (2)), whereas the model that describes the relationship between DT and the concentrations of caryophyllene was Power (convex) (Equation (3)). There was no relationship between DT and pregeijerene B.

For J. excelsa, the most appropriate regression model that describes the relationship between DT and EO content, as well as the concentration of limonene, was Power (convex) (Equation (3)), whereas the model that describes the relationship between DT and the concentration of cedrol was Michaelis-Menten (Equation (4)). There was no relationship between DT and the concentration of $\alpha$-pinene.

For J. sabina, the most appropriate regression model that describes the relationship between DT and EO content, as well as the concentrations of $\alpha$-thujene, $\alpha$-pinene, sabinene, $\beta$-pinene, and limonene, was Power (convex) (Equation (3)), whereas the relationship between DT and the concentrations of terpinen-4-ol and methyl eugenol was best described by the Asymptotic (convex) (Equation (2)) model. There was no relationship between DT and the concentration of citronellic acid methyl ester.

$$
\begin{gathered}
Y=\beta_{0}+\beta_{1} X+\beta_{2} X^{2}+\beta_{3} X^{3}+\varepsilon \\
Y=\theta_{1}-\theta_{2}\left(\exp \left(-\theta_{3} X\right)\right)+\varepsilon \\
Y=\theta_{1} X^{\theta_{2}}+\varepsilon \\
Y=\frac{\theta_{1} X}{\theta_{2}+X}+\varepsilon
\end{gathered}
$$


where $\mathrm{Y}$ is the dependent (response) variable, $\mathrm{X}$ is the independent (DT) variable, and the error term $\varepsilon$ is assumed to have normal distribution with constant variance.

While the third-order polynomial model (Equation (1)) is linear, the other three models (Asymptotic, Power, and Michaelis-Menten) are nonlinear and their parameters were estimated iteratively using the NLIN Procedure of SAS [67], and the fitted models met all the adequacy requirements of nonlinear models [68]. The figures, as well as the third-order polynomial model, fits were prepared using Minitab 18 software (Minitab, State College, PA, USA).

\section{Conclusions}

This experiment enabled to model the elution of various EO constituents and to pinpoint the oil fractions of J. virginiana, J. excelsa, and J. sabina with the specific oil composition and the EO with the highest in vitro antioxidant capacity at different distillation timeframes. The study demonstrated that, by manipulating DT and capturing fractions at specific time points, one can capture the desired composition of EO with less time and energy. The results of this study could be a significant finding for the pharmaceutical, aromatic, and other industries that use the EO of J. virginiana, J. excelsa, and J. sabina.

Author Contributions: Conceptualization, V.Z. and I.S.; Methodology, V.Z., I.S., C.C., T.A., and V.S.; Software, C.C. and T.A.; Validation, I.S., V.Z., C.C., T.A., S.S., V.S., and T.R.; Formal Analysis, C.C. and T.A.; Investigation, I.S., V.Z., C.C., T.A., V.S.; Resources, I.S., V.Z., C.C., T.A., S.S., and V.S.; Data Curation, I.S., V.Z., C.C., T.A., and V.S.; Writing-Original Draft Preparation, I.S., S.S. and V.Z; Writing—Review and Editing, I.S., V.Z., C.C., T.A., S.S., and T.R.; Visualization, T.A.; Supervision, V.Z; Project Administration, V.Z.; Funding Acquisition, V.Z. and C.C."

Funding: This study was supported by Oregon State University funds awarded to Dr. Valtcho Jeliazkov (Zheljazkov).

Acknowledgments: Authors thank Mrs. Vassilka Petkova and Mrs. Yulia Yonkova at the Research Institute for Roses and Medicinal Plants in Kazanluk, Bulgaria, for their help with the essential oil extraction.

Conflicts of Interest: The authors declare no conflict of interest.

\section{References}

1. Khan, M.; Khan, A.; Najeeb-ur-Rehman; Gilani, A. Pharmacological explanation for the medicinal use of Juniperus excelsa in hyperactive gastrointestinal and respiratory disorders. J. Nat. Med. 2012, 66, 292-301. [CrossRef] [PubMed]

2. Seca, A.; Silva, A. The chemical composition of the Juniperus genus (1970-2004). In Recent Progress in Medicinal Plants, vol. 16. Phytomedicines; Govil, J.N., Singh, V.K., Bhardwaj, R., Eds.; Studium Press LLC: Houston, Texas, USA, 2006; pp. 401-522.

3. Yesenofski, J. Juniper Oil Distillation and Marketing Project Western Juniper Commercialization Program Final Report, Ver. 2. The Confederated Tribes of the Warm Springs Reservation of Oregon, Business \& Economic Development Branch. 1996. Available online: http://juniper.orst.edu/wjoils.htm (accessed on 8 March 2019).

4. Madej, T.; Pirożnikow, E.; Dumanowski, J.; Łuczaj, Ł. Juniper Beer in Poland: The Story of the Revival of a Traditional Beverage. J. Ethnobiol. 2014, 34, 84-103. [CrossRef]

5. Raut, J.S.; Karuppayil, S.M. A status review on the medicinal properties of essential oils. Ind. Crops Prod. 2014, 62, 250-264. [CrossRef]

6. Yarnell, E. Botanical medicines for the urinary tract. World J. Urol. 2002, 20, 285-293. [PubMed]

7. Sela, F.; Karapandzova, M.; Stefkov, G.; Kulevanova, S. Chemical composition of berry essential oils from Juniperus communis L. (Cupressaceae) growing wild in Republic of Macedonia and assessment of the chemical composition in accordance to European Pharmacopoeia. Maced. Pharm. Bull. 2011, 57, 43-51.

8. Saab, A.M.; Guerrini, A.; Sacchetti, G.; Maietti, S.; Zeino, M.; Arend, J.; Gambari, R.; Bernardi, F.; Efferth, T. Phytochemical analysis and cytotoxicity towards multidrug-resistant leukemia cells of essential oils derived from Lebanese medicinal plants. Planta Med. 2012, 78, 1927-1931. [CrossRef] [PubMed] 
9. Huyan, T.; Li, Q.; Wang, Y.L.; Li, J.; Zhang, J.Y.; Liu, Y.X.; Shahid, M.R.; Yang, H.; Li, H.Q. Anti-tumor effect of hot aqueous extracts from Sonchus oleraceus (L.) L. and Juniperus sabina L.-Two traditional medicinal plants in China. J. Ethnopharmacol. 2016, 185, 289-299. [CrossRef] [PubMed]

10. Kakar, H.; Sajjad, A.; Rizwan, S.; Mahmood, K.; Mehmood, Z.; Azam, M.; Hafeez, I.; Sarangzai, A.M.; Nadhman, A.; Yasinzaia, M. Chemical composition, antimicrobial and antileishmanial activity of essential oil of Juniperus excelsa M.Bieb. from Ziarat, Balochistan. Pure Appl. Biol. 2017, 6, 786-796. [CrossRef]

11. Kagawa, K.; Tokura, K.; Uchida, K.; Kakushi, H.; Shike, T.; Kikushi, J.; Nakai, H.; Dorji, P.; Subedi, L. Platelet aggregation inhibitors in a Bhutanese medicinal plant, Shug Chher. Chem. Pharm. Bull. 1993, 41, 1604-1607. [CrossRef] [PubMed]

12. Gao, R.; Gao, C.; Tian, X.; Yu, X.; Di, X.; Xiao, H.; Zhang, X. Insecticidal activity of deoxypodophyllotoxin, isolated from Juniperus sabina $\mathrm{L}$, and related lignans against larvae of Pieris rapae L. Pest. Manag. Sci. 2004, 60, 1131-1136. [CrossRef] [PubMed]

13. Djeridane, A.; Yousfi, M.; Nadjemi, B.; Boutassouna, D.; Stocker, P.; Vidal, N. Antioxidant activity of some Algerian medicinal plants extract containing phenolic compounds. Food Chem. 2006, 97, 654-660. [CrossRef]

14. Emami, S.A.; Abedindo, B.F.; Hassanzadeh-Khayyat, M. Antioxidant activity of the essential oils of different parts of Juniperus excelsa M. Bieb. subsp. excelsa and J. excelsa M. Bieb. subsp. polycarpos (K. Koch) Takhtajan (Cupressaceae). Iran. J. Pharm. Res. 2011, 10, 799-810.

15. Zheljazkov, V.D.; Semerdjieva, I.B.; Dincheva, I.; Kacaniova, M.; Astatkie, T.; Radoukova, T.; Schlegel, V. Antimicrobial and antioxidant activity of Juniper galbuli essential oil constituents eluted at different times. Ind. Crops Prod. 2017, 109, 529-537. [CrossRef]

16. Cantrell, C.L.; Zheljazkov, V.D.; Osbrink, W.L.A.; Castro, A.; Maddox, V.; Craker, L.E.; Astatkie, T. Podophyllotoxin and essential oil profile of Juniperus and related species. Ind. Crops Prod. 2013, 43, 668-676. [CrossRef]

17. Zheljazkov, V.; Astatkie, T.; Jeliazkova, E. Year-round variations in essential oil content and composition of Male and Female Juniper. HortScience 2013, 48, 883-886. [CrossRef]

18. Zheljazkov, V.D.; Astatkie, T.; Jeliazkova, E.; Tatman, A.O.; Schlegel, V. Distillation time alters essential oil yield, composition and antioxidant activity of female Juniperus scopulorum trees. J. Essent. Oil Res. 2013, 25, 62-69. [CrossRef]

19. Avci, A.B.; Bilir, N. Variation in Essential Oil Content and Composition of Crimean Juniper (Juniperus excelsa) Berries during the Growth Periods. J. Essent. Oil Bear. Plants 2014, 17, 478-485. [CrossRef]

20. Pavićević, V.P.; Radović, M.N.; Milojević, S.Ž.; Marković, M.S.; Ristić, M.S.; Povrenović, D.S. Influence of hydrodistillation rate and hydromodule on chemical composition of Juniperus communis L. essential oil. Hem. Ind. 2017, 71, 1-10. [CrossRef]

21. Uçar, G.; Balaban, M. The composition of volatile extractives from the wood of Juniperus excelsa, Juniperus foetidissima and Juniperus oxycedrus. Holz als Roh- und Werkstoff 2002, 60, 356-362. [CrossRef]

22. Unlu, M.; Unlu, G.V.; Vural, N.; Donmez, E.; Akmak, O. Composition and antibacterial activity of Juniperus excelsa essential oil. Chem. Nat. Comp. 2008, 44, 129-131. [CrossRef]

23. Al-Busafi, S.; Al-Saidi, S.; Al-Riyami, A.; Al-Manthary, N. Comparison of chemical composition and antioxidant activity of four essential oils extracted from different parts of Juniperus excelsa. Sultan Qaboos Univ. J. Sci. 2016, 21, 7-15. [CrossRef]

24. Shanjani, P.S.; Mirza, M.; Calagari, M.; Adams, R.P. Effects drying and harvest season on the essential oil composition from foliage and berries of Juniperus excelsa. Ind. Crops Prod. 2010, 32, 83-87. [CrossRef]

25. Zheljazkov, V.D.; Astatkie, T.; Jeliazkova, E.; Schlegel, V. Distillation time alters essential oils yeld, composition, and antioxidant activity of male Juniperus scopolorum trees. J. Oleo Sci. 2012, 61, 537-546. [CrossRef] [PubMed]

26. Cantrell, C.L.; Zheljazkov, V.D.; Carvalho, C.R.; Astatkie, T.; Jeliazkova, E.; Rosa, L. Dual Extraction of Essential Oil and Podophyllotoxin from Creeping Juniper (Juniperus horizontalis). PLoS ONE 2014, 9, e106057. [CrossRef] [PubMed]

27. Adams, R.P. The chemical composition of leaf oils of Juniperus excelsa M. Bieb. J. Essent. Oil Res. 1990, 2, 45-489. [CrossRef]

28. Gawde, A.J.; Cantrell, C.L.; Zheljazkov, V.D. Dual extraction of essential oil and podophyllotoxin from Juniperus virginiana. Ind. Crops Prod. 2009, 30, 276-280. [CrossRef] 
29. Gawde, A.J.; Zheljazkov, V.D.; Maddox, V.; Cantrell, C.L. Bioprospection of Eastern red cedar from nine physiographic regions in Mississippi. Ind. Crops Prod. 2009, 30, 59-64. [CrossRef]

30. Eller, F.; Clausen, C.; Green, F.; Taylor, S.F. Critical fluid extraction of Juniperus virginiana L. and bioactivity of extracts against subterranean termites and wood rot fungi. Ind. Crops Prod. 2010, 32, 481-485. [CrossRef]

31. Eller, F.J.; Vander Meer, R.K.; Behle, R.W.; Flor-Weiler, L.B.; Palmquist, D.E. Bioactivity of Cedarwood Oil and Cedrol Against Arthropod Pests. Environ. Entomol. 2014, 43, 762-766. [CrossRef] [PubMed]

32. Muhammad, I.; Mossa, J.S.; El- Feraly, F.S. Antibactrial diterpenes from the leaves and seeds of Juniperus excelsa M. Bieb. Phytother. Res. 1992, 6, 261-264. [CrossRef]

33. Yesilada, E.; Honda, G.; Sezik, E.; Tabata, M.; Fujita, T.; Tanaka, T.; Takeda, Y.; Takaishi, Y. Traditional medicine in Turkey. V. Folk medicine in the inner Taurus Mountains. J. Ethnopharmacol. 1995, 46, 133-152. [CrossRef]

34. Fujita, T.; Sezik, E.; Tabata, M. Traditional medicine in Turkey VIIl. Folk medicine in middle and west black sea regions. Econ. Bot. 1995, 49, 406-422. [CrossRef]

35. Emami, S.A.; Asgary, S.; Naderi, G.A.; Shams Ardekani, M.R.; Kasher, T.; Aslani, S.; Airin, A.; Sahebkar, A. Antioxidant activities of Juniperus foetidissima essential oils against several oxidative systems. Rev. Bras. Farmacogn. 2011, 21, 627-634. [CrossRef]

36. Thappa, R.K.; Aggarwal, S.G.; Kapahi, B.K.; Sarin, Y.K. Juniperus excelsa leaf oil, a new source of cedrol. J. Nat. Prod. 1987, 50, 323-324. [CrossRef]

37. Lindh, J.; Okal, M.; Herrera-Varela, M.; Borg-Karlson, A.K.; Torto, B.; Lindsay, S.; Fillinger, U. Discovery of an oviposition attractant for gravid malaria vectors of the Anopheles gambiae species complex. Malar. J. 2015, 14, 119. [CrossRef]

38. Eneh, K.L.; Saijo, H.; Borg-Karlson, A.; Lindh, J.M.; Rajarao, G.T. Cedrol, a malaria mosquito oviposition attractant is produced by fungi isolated from rhizomes of the grass Cyperus rotundus. Malar. J. 2016, 15, 478. [CrossRef] [PubMed]

39. von Rudloff, E. Gas liquit cgromatography of Trepenes part AS-LIQUID IX. The volatile oil of the leaeves of Juniperus sabina L. Can. J. Chem. 1963, 41, 2876-2881. [CrossRef]

40. Chemat, F.; Vian, M.A.; Cravotto, G. Green extraction of natural products: Concept and principles. Int. J. Mol. Sci. 2012, 13, 8615-8627. [CrossRef] [PubMed]

41. Adams, R.P. Investigation of Juniperus species of the United States for new Sources of Cedar wood Oil. Econ. Bot. 1987, 41, 48-54. [CrossRef]

42. Mourad, A.K.; Zaghloul, O.A.; El Kady, M.B.; Nemat, F.M.; Morsy, M.E. A novel approach for the management of the chalkbrood disease infesting honeybee Apismellifera L. (Hymenoptera: Apidae) colonies in Egypt. Commun. Agric. Appl. Biol. Sci. 2005, 70, 601-611. [PubMed]

43. Francisco, C.S.; Messiano, G.B.; Lope, L.M.X.; Tininis, A.G.; De Oliveira, J.E.; Capellari, L., Jr. Classification of Aristolochia species based on GC-MS and chemometric analyses of essential oils. Phytochem. 2008, 69, 168-175. [CrossRef] [PubMed]

44. Shiwakoti, S.; Poudyal, S.; Saleh, O.; Astatkie, T.; Zheljazkov, V.D. Method for attaining caraway seed oil fractions with different composition. Chem. Biodivers. 2016, 13, 695-699. [CrossRef] [PubMed]

45. Dunford, N.T.; Hiziroglu, S.; Holcom, R. Effect of age on the distribution of oil in Eastern red cedar tree segments. Bioresour. Technol. 2007, 98, 2636-2640. [CrossRef] [PubMed]

46. Shiwakoti, S.; Saleh, O.; Poudyal, S.; Barka, A.; Qian, Y.; Zheljazkov, V.D. Yield, composition and antioxidant capacity of the essential oil of sweet basil and holy basil as influenced by distillation methods. Chem. Biodivers. 2017, 14, e1600417. [CrossRef] [PubMed]

47. Breitmeier, E. Terpenes: Flavors, Fragrances, Pharmaca, Pheromones; Wiley: Wiley-VCH Verlag GmbH \& Co. KGaA: Weinheim, Germany, 2006; pp. 46-47.

48. Chen, S.S.; Qiu-Li, Y.Z.; Lin, Z.; Zhao, Y. Preventive effects of cedrol against alopecia in cyclophosphamide-treated mice. Environ. Toxicol. Pharmacol. 2016, 46, 270-276. [CrossRef] [PubMed]

49. Kim, W.; Lee, D.H. Cosmetic Composition for Preventing or Ameliorating Hypersensitive Skin Comprising Cedrol or Derivatives Thereof, or Pharmaceutically Acceptable Salts Thereof. U.S. Patent Application 15/945,601, 11 October 2018.

50. Bhatia, S.P.; McGinty, D.; Letizia, C.S.; Api, A.M. Fragrance material review on cedrol. Food Chem. Toxicol. 2008, 46, S100-S102. [CrossRef] [PubMed] 
51. Asili, J.; Emami, S.A.; Rahimizadeh, M.; Fazly-Bazzaz, B.S.; Hassanzadeh, M.K. Chemical and Antimicrobial Studies of Juniperus sabina L. and Juniperus foetidissima Willd. Essential Oils. J. Essent. Oil Bear. Plants 2008, 13, 25-36. [CrossRef]

52. Fournier, G.; Pages, N.; Fournier, C.; Gallen, G. Contribution to the study of the Essential Oil of various cultivars of Juniperus sabina. Planta Med. 1991, 57, 392-393. [CrossRef] [PubMed]

53. U.S. Food and Drug Administration. FDA Removes 7 Synthetic Flavoring Substances from Food Additives List. 2018. Available online: https:/ / www.fda.gov/Food/NewsEvents/ConstituentUpdates/ucm622475. htm (accessed on 3 January 2019).

54. Buchbauer, G. Biological Activities of Essential Oils. In Handbook of Essential Oils: Science, Technology, and Applications; Baser, K.H.C., Buchbauer, G., Eds.; CRC Press/Taylor \& Francis Group: Boca Raton, FL, USA, 2010; pp. 235-280.

55. Editorial. Antioxidant methods. J. Food Compos. Anal. 2017, 64, 145-146. [CrossRef]

56. Granato, D.; Shahidi, F.; Wrolstad, R.; Kilmartin, P.; Melton, L.D.; Hidalgo, F.J.; Miyashita, K.; van Camp, J.; Alasalvar, C.; Ismailj, A.B.; et al. Antioxidant activity, total phenolics and flavonoids contents: Should we ban in vitro screening methods? Food Chem. 2018, 264, 471-475. [CrossRef] [PubMed]

57. Teixeira, B.; Marques, A.; Ramos, C.; Neng, N.R.; Nogueira, J.M.; Saraiva, J.A.; Nunes, M.L. Chemical composition and antibacterial and antioxidant properties of commercial essential oils. Ind. Crops Prod. 2013, 43, 587-595. [CrossRef]

58. Koh, K.J.; Pearce, A.L.; Marshman, G.; Finlay-Jones, J.J.; Hart, P.H. Tea tree oil reduces histamine-induced skin inflammation. Br. J. Dermatol. 2002, 147, 1212-1217. [CrossRef] [PubMed]

59. Isman, M. Pesticides Based on Plant Essential Oils: Phytochemical and Practical Considerations. In Medicinal and Aromatic Crops: Production, Phytochemistry, and Utilization; Zheljazkov, V.D., Cantrell, C.L., Eds.; American Chemical Society: Washington, DC, USA, 2016; Chapter 2; pp. 13-26.

60. Emami, S.A.; Asili, J.; Mohagheghi, Z.; Hassanzadeh, M.K. Antioxidant activity of leaves and fruits of Iranian conifers. Evid. Based Complement. Altern. Med. 2007, 4, 313-319. [CrossRef] [PubMed]

61. Zheljazkov, V.D.; Kacaniova, M.; Dincheva, I.; Radoukova, T.; Semerdjieva, I.B.; Astatkie, T.; Schlegel, V. Essential oil composition, antioxidant and antimicrobial activity of the galbuli of six juniper species. Ind. Crops Prod. 2018, 124, 449-458. [CrossRef]

62. Thiers, B. Index Herbariorum: A Global Directory of Public Herbaria and Associated Staff. New York Botanical Garden's, 2012. [Continuously Updated]. Virtual Herbarium. Available online: http:/ / sweetgum. nybg.org/ih/ (accessed on 25 June 2018).

63. Adams, R.P. Identification of Essential Oil Components by Gas Chromatography Mass Spectrometry, 4th ed.; Allured Books: Carol Stream, IL, USA, 2007.

64. Huang, D.; Ou, B.; Hampsch-Woodill, M.; Flanagan, J.; Demmer, E.K. Development and validation of oxygen radical absorbance capacity assay for lipophilic antioxidants using randomly methylate B-cylodextrin as the solubility enhancer. J. Agric. Food Chem. 2002, 50, 1815-1821. [CrossRef] [PubMed]

65. Huang, D.; Ou, B.; Hampsch-Woodill, M.; Flanagan, J.; Prior, R. High-throughput assay of oxygen radical absorbance capacity (ORAC) using a multichannel liquid handling system coupled with a microplate fluorescence reader in 96-well format. J. Agric. Food Chem. 2002, 50, 4437-4444. [CrossRef] [PubMed]

66. Montgomery, D.C. Design and Analysis of Experiments, 9th ed.; Wiley: Hoboken, NJ, USA, 2017.

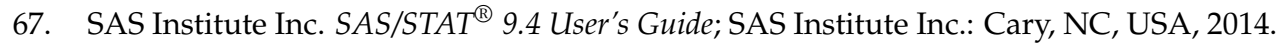

68. Bates, D.M.; Watts, D.G. Nonlinear Regression and Its Applications; Wiley: Hoboken, NJ, USA, 2007.

Sample Availability: Samples of the compounds (the essential oils from the controls of each of the three species) are available from Dr. Valtcho D. Zheljazkov.

(C) 2019 by the authors. Licensee MDPI, Basel, Switzerland. This article is an open access article distributed under the terms and conditions of the Creative Commons Attribution (CC BY) license (http:/ / creativecommons.org/licenses/by/4.0/). 